\section{S-100 Protein in Embryonic Chick Retinae}

Embryonic differentiation presumably reflects differential gene expression ${ }^{1}$. It has been pointed out that the retina is particularly well suited for studies of these phenomena ${ }^{2,3}$ because of its ease of isolation, lack of vascularization, discrete origin and well studied pattern of morphogenesis ${ }^{4,5}$.

Gene expression in the differentiating colls of the nervous system has been most conveniently investigated by analysis of enzyme activity ${ }^{6,7}$. For systems in which the enzyme pathways have not been worked out immunochemical methods can be used. Like the enzyme assays, immunochemical methods are specific and quantifiable, and are applicable to non-catalytic substances as well as enzymes; the availability of purified antigens and highly specific antisera makes them easy to use. 'These conditions were met by the isolation and purification of a highly acidic protein, termed S-100, unique to the nervous system $^{8}$, and by the subsequent production of antibodies against this protein.

We have traced the pattern of accumulation in tho embryonic chick retina of this well characterized "endproduct" protein of no known enzyme activity, and related this pattern to metabolic changes which occur during differentiation.

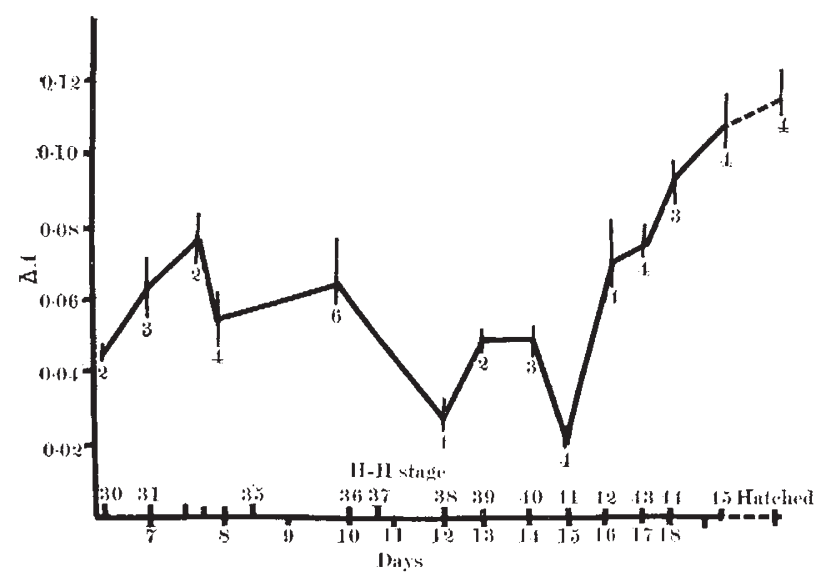

Fig. 1. Accumulation of $\mathbf{S}-100$ protein in embryonic chick retinae. indicate number of retinge tested. H-II= 1 amburger Hamilton stage. There was $2 \mu$ g total protein per tube.

Antisera to purified beef S-100 were prepared in rabbits as previously described ${ }^{9}$. Embryos from New Hampshire Red eggs incubated at $38^{\circ}-39^{\circ} \mathrm{C}$ in a forced draft incubator were removed at various times, floated in saline to remove adhering yolk and staged according to the Hamburger and Hamilton stage series ${ }^{10}$. The lower temporal quadrant of the retina of each eye was excised under a stereoscopic microscope using watchmaker's forceps and iridectomy scissors. The pigment and noural layers wero separated and the neural retinae were immediately homogenized in micro-glass homogenizers using $130 \mu \mathrm{l}$. of cold, triple distilled water.

The homogenates were divided into small aliquots, stored at $-80^{\circ} \mathrm{C}$ and each thawed only once for determination of protein ${ }^{11}$ and assay of $\mathrm{S}-100$. The relative concentration of S-100 in the embryonic chick retinae was determined by a micro-complement fixation assü ${ }^{9}$, and the degree of lysis was determined by spectrophotometric measuroment of released hacmoglobin. Because absolute concentrations of $\$-100$ could not be determined in this assay we expressed results as amount of fixation (decrement in optical density of haemoglobin from lysed erythrocytes) relative to total retinal protein.

After dropping from an initial peak at 7.75 days, retinal S-100 concentration, relative to total protein, increases by a factor of about five between 15 days of incubation, when it was minimal, and 18 days of incubation (Fig. 1). The increase in relative $\mathrm{S} \cdot 100$ concentration continues until at least 2 weeks after hatching. To obtain an approximation of the absolute concentration of S-100 in chick retinae, known concentrations of purified beef $\mathrm{S}-100$ were tested by complement fixation against the same fixed concentration of antiserum used in the retinal assays ${ }^{9}$. Chick retinal homogenates contain $\mathrm{S} \cdot 100$ in amounts of the order of $2 \times 10^{-8} \mathrm{~g} / \mathrm{ml}$. of homogenate at early embryonic stages and $1.5 \times 10^{-5} \mathrm{~g} / \mathrm{ml}$. of homogenato at 18 days of incubation. The assumption has been made that brain and retinal $\mathbf{S - 1 0 0}$ are similar in immunological reactivity. These data establish that $\mathrm{S}-100$ constitutes less than $0 \cdot 1$ per cent of the total retinal protein at 6.5 days and rises to about 0.5 per cent of the total by 19 days of incubation.

Statistical analysis of the peak between 15 and 16 days shows it to be significant at a level of $P=0.014$ using the Mann-Whitney $U$ test. The same test, applied to the decrease occurring between 7.75 and 15 days, yields a value of $P=0.067$ which is the greatest level of significance obtainable for the sample sizes involved.

Although the present data are not directly comparable with values obtained by Friedman and Wenger ${ }^{9}$ on whole brain, the S-100 content of the retina at about 7 days relative to the eventual level (about 66 per cent) corresponds to the value of $7 \cdot 75$ day brain conpared with the adult level. This suggests that the retina follows a pattern of S-100 accumulation similar to that of whole brain up to this time. From 7.75 to 15 days, however, the decrease in relative $\mathrm{S}-100$ concentration suggests a more rapid accumulation of other proteins.

The rapid increase between 15 and 18 days coincides with increased glutamine synthetase ${ }^{3}$ and alkaline phosphatase $^{12}$ and occurs concurrently with the functional maturation of the eye ${ }^{2}$. Cicero, Cowan and Moore (personal communication) have found a similar increaso in S-100 content of the chick optic tectum between 16 and 18 days of incubation. This period seems critical for the differentiation of the visual system in the chick.

This work was supported in part by a grant from the University of Missouri, St Louis, to H. F. We thank Miss Mary Ruscha for technical assistance.

\section{B. WHNGER}

Department of Anatomy,

University of Saskatchewan,

Saskatoon, Saskatchewan,

Canada.

H. Friedman

Department of Biology,

University of Missouri-St Tonis,

8001 Natural Bridge Road,

St Louis, Missouri.

Received April 24, 1970.

1 Stern, C., in Analysis of Development (edit. by Willier, R., Weiss, P., and Hamburger, V.), 151 (Saunders, Philadelphia, 1955).

${ }^{2}$ Coulombre, A. T., Amer. J. Anal., 98, 153 (1955).

${ }^{3}$ Moscona, A. A., and Hubby, J. T., Develop. Biol., 7, 192 (1963).

- Coulombre, A. J., Intern. Rev. Cytol., 11, 161 (1961).

s Kirk, D. L., and Moscona, A., Jerelon. Biol., 8, 341 (1963).

'Herrmann, H., and Tootle, M. T., Physiol. Rev., 44, 289 (19ю4).

"Scarano, F., and Augusti-Iocco, G., Comp. Biochem., 28, 55 (1967).

8 Moore, B. W., Biochem. Biophys. Res. Commun., 19, 739 (1965).

${ }^{9}$ Friedman, H. P., and Wenger, B. S., J. Embryol. Exp. Morkhol., 23, 289 $(1970)$.

${ }^{10}$ Hamburger, Y., and Hamilton, H. L., J. Morphol., 88, 49 (1951).
${ }^{1}$ Lowry, O. Tr., Rosebreugl, N. J., Harr, A. L., and Randall, R. J., J. Hiol. Chem., 193, 265 (1951).

${ }^{2} \mathrm{Moog}, \mathrm{F}, \mathrm{Ann.} N Y$ A cexd. Sci., 55, 57 (1952). 